\title{
The OECD Guidelines for Multinational Enterprises on Responsible Business Conduct
}

\author{
Soft Law with Hard Consequences
}

Roel Nieuwenkamp*

\section{The Nature of the OECD Guidelines for Multinational Enterprises}

A cautionary tale related to responsible business conduct is told by the famous movie Avatar. This James Cameron movie is about a mining company from Earth that starts mining on the holy mountain of the alien indigenous people, the Navi. The company made all the typical corporate social responsibility (CSR) mistakes. They did not conduct a proper due diligence on human rights. They did not organize a good stakeholder consultation. They did not get any 'free prior informed consent' from the local community. Of course, this led to an egregious breach of human rights of the local community. In the end, it led to a war. The company lost the war, with its personnel kicked out of the planet.

This movie deals with a well-known CSR problem in the extractive industries in real life. Many companies in the mining and oil industries struggle with similar issues of corporate responsibility.

The link to the Organisation of Economic Co-operation and Development (OECD) Guidelines for Multinational Enterprises ${ }^{1}$ (the 'OECD Guidelines') is not too hard to make. The mining company Vedanta, a company listed in the UK, started mining on holy ground in India. This led to a big problem with the indigenous people, the 'Dongria Kondh'. A group of non-governmental organizations (NGOs) made a complaint to the National Contact Point (NCP) for the OECD Guidelines in the United Kingdom, alleging that Vedanta had breached the OECD Guidelines. The NCP tried to find a mediated solution; however, the company did not want to engage in the mediation. The NCP issued a

* Prof. Dr. Roel Nieuwenkamp is Chair of the OECD Working Party on Responsible Business Conduct. In this capacity, he supervises the corporate responsibility work of the OECD, invests in outreach to non-adherent countries and provides leadership to CSR programmes, e.g. on the financial sector, mining sector, etc. Since 2010, he is part-time professor of public administration at the University of Amsterdam.

1. <www.oecd.org/daf/inv/mne/oecdguidelinesformultinationalenter prises.htm>. so-called final statement that Vedanta did not want to engage in mediation and breached the human rights provisions in the OECD Guidelines. ${ }^{2}$

The statement of the NCP was used by some trade unions and NGOs to lobby the financial sector to influence and change the behaviour of Vedanta. Especially institutional investors, like pension funds which have a strong sustainability perspective, have put Vedanta on their 'hit-list' for engagement and some investors threatened to sell their stake. Some investors sold their shares, which gave a very strong signal to sustainable investors. This is a nightmare to every company that deems itself a respectful enterprise.

The main lesson from this cautionary tale is that although the OECD Guidelines are voluntary for business enterprises, they should not be taken too lightly. It is soft law with hard consequences. ${ }^{3}$

In this article, I will describe the nature of the OECD Guidelines, as well as the highlights of the revisions in the 2011 edition of the OECD Guidelines, including human rights and supply chain responsibility. Furthermore, I will elaborate on the theme 'soft law with hard consequences'. I will conclude with a couple of futureoriented remarks.

\section{The OECD Guidelines for Multinationals on Responsible Business Conduct}

The Guidelines constitute the most comprehensive government-backed code of conduct that enterprises are expected to observe wherever they operate. They cover all relevant areas of corporate responsibility: human rights, labour rights, environment, corruption, taxation, disclosure and so forth. The principles and standards they promote are consistent with applicable laws, and internationally recognized standards. They are known

2. UK National Contact Point, March 2010, Final Statement Survival International vs. Vedanta Resources Plc.

3. See also, for an analysis of the legal aspects of the NCP procedure, Backer 2009. 
for their unique implementation procedures that include NCPs in all adhering countries and a mediation mechanism for addressing complaints involving alleged breaches of the OECD Guidelines by multinational enterprises (MNEs), in the words of the Guidelines called specific instances. Besides these, NCPs shall promote the Guidelines.

The Guidelines, which are an annex to the OECD's Declaration on International Investment and Multinational Enterprises, ${ }^{4}$ are non-binding for multinationals. However, they are binding for governments, which have an obligation to implement and promote them by jointly recommending to MNEs operating in or from their territories the observance of the Guidelines. This 'hardens' the soft law characteristics of the Guidelines. ${ }^{5}$

An important distinction is made between a lot of 'private' CSR standards, like ISO 26000, UN Global Compact, Global Reporting Initiative, etc. and 'public' CSR standards, which are negotiated by governments after intense consultations with employer organizations, trade unions and NGOs. The International Labour Organisation (ILO) tripartite declaration on MNEs and the OECD Guidelines belong to the last category. Many governments therefore use in the public debate on CSR issues the public standards as a benchmark and they have 'soft law' status.

Thirty-four OECD members and eleven non-OECD countries currently subscribe to them. It is important to stress that this is no longer a 'rich men's' club. Among the adherent governments are Brazil, Argentina, Colombia, Jordan, Tunisia and Morocco. Several other governments, like Russia, are in various stages of their application process. With several other countries like India, the OECD Working Party on Responsible Business Conduct is setting up working relationships.

The group of adherents represent a diversity of countries in different stages of development. Besides, the group has a wide regional spread across the globe. Around 85 percent of global trade and flows of foreign direct investment are covered by the OECD Guidelines. The OECD Guidelines' state-of-the-art supply-chainresponsibility provisions cover important supply relations between developed and developing countries, for example, the Chinese Foxconn supply chain to Apple consumers, ${ }^{6}$ the Bangladeshi textiles supply chains to the OECD clothing consumers ${ }^{7}$ and the Congolese minerals supply chain to the buyers of mobile phones. ${ }^{8}$

It is clearly a very relevant standard in this globalized world, although a lot of work remains to be done on outreach to Asian and African countries, which are still underrepresented.

4. <www.oecd.org/daf/inv/mne/oecdguidelinesformultinationalenter prises.htm>.

5. See on the relation between hard law and soft law and their interaction, Shaffer \& Pollack 2009

6. See <www.theguardian.com/technology/2013/jul/29/apple-investu gates-claims-china-factory $>$.

7. See <www.dw.de/bangladesh-textile-workers-fed-up-with-conditions/ a-17114602>.

8. See <www.theguardian.com/sustainable-business/blog/congo-childlabour-mobile-minerals $>$.

\section{Major Revisions in 2011}

On 25 May 2011, US Secretary of State Hillary Clinton joined colleague ministers from members of the OECD and developing economies to celebrate the organization's 50th anniversary and chaired the signing session of the agreement on an update of the OECD Guidelines for Multinational Enterprises, the fifth revision since their adoption in 1976. This marked the culmination of an intense multiple-year negotiating process involving a large number of stakeholders, international organizations and emerging economies.

The 2011 update concentrated on three major issues.

a. Human Rights

The first was the incorporation of a nem chapter on human rights, based on the concept "protect, respect and remedy" - the Framework and the respective Guiding Principles developed by the UN Special Representative for Business and Human Rights, Professor John Ruggie. ${ }^{9}$ The OECD Guidelines now more clearly define responsible business conduct of MNEs, particularly in the area of human rights (Chapter 4).

The OECD and United Nations' Secretary-General Special Representative on the issue of Business and Human Rights, John Ruggie, worked intensively together to draft this chapter. As a result, the Guidelines fully reflect the Guiding Principles on Business and Human Rights, which were unanimously endorsed by the United Nations Human Rights Council in June 2011. ${ }^{10}$

The fact that the 'endorsed' UN Guiding Principles became a binding government negotiated commitment via the OECD Ministerial Decision strengthens the nature of the corporate responsibility to respect human rights, which, in Ruggie's words, are to be characterized as a global standard of expected conduct, by providing this standard with a soft law basis. Besides, the OECD Guidelines are among the first international instruments to operationalize the UN Protect, Respect and Remedy Framework 2008, and the only one offering a ready-to-use governmental complaints mechanism for cross-border violations of human rights. Apart from the 'soft' legal perspective, this cooperation between the UN and the OECD also paid off from the business perspective. It is better for businesses to have a coherent framework on CSR than to be expected to take into account different provisions.

The incorporation of a human rights chapter in the Guidelines represents a significant milestone.

9. UN Protect, Respect and Remedy Framework 2008, A/HRC/8/5, 7 April 2008 and the UN Guiding Principles A/HRC/17/31, 21 March 2011. The full text of the Guiding Principles is available at $<$ www.ohchr.org/Documents/Publications/GuidingPrinciplesBusinessHR_EN.pdf>.

10. UN General Assembly A/HRC/RES/17/4, 6 July 2011. 
b. Supply Chain

US Secretary of State, Hillary Clinton, said at the adoption of the update: "If you look at these guidelines, they will be helping us determine how supply chains can be changed so that it can begin to prevent and eliminate abuses and violence. We're going to look at new strategies that will seek to make our case to companies that due diligence, while not always easy, is absolutely essential." This statement reflects the second milestone of the update of the Guidelines: the introduction of nem standards on supply chain responsibility.

A key provision that has been newly introduced in the Guidelines states that MNEs should avoid causing or contributing to adverse impacts on the social, environmental and other interests to which the Guidelines relate. This provision covers MNEs' activities and also the direct involvement of MNEs in activities in the supply chain. When an adverse impact occurs to which MNEs did not contribute, MNEs are expected to examine possibilities to avoid such impacts if there is a direct linkage between the impacts and the activities of MNEs as a consequence of a business relationship. However, this is not intended to shift responsibility from the entity causing an adverse impact to the MNE with which it has a business relationship. ${ }^{11}$

A related provision expects companies to carry out risk-based due diligence to identify, prevent and mitigate actual and potential adverse impacts as mentioned above. This new provision is applicable to all chapters, except those dealing with science and technology, competition and taxation. It is important to emphasize that this provision has extended the scope of the guidelines from an investmentnexus, which had been the main condition for the OECD Guidelines' applicability till 2011, to supply chains. This increased the relevance of the guidelines in a globalized economy. It is a risk-based provision that is not alien to businesses because businesses are intrinsically interested in the management of risks. A cautionary comment is in order here, since it is also a provision that allows for mistakes: it does not require a 'zero tolerance' approach. Prioritization is possible on the basis of the severity of risks. This is often necessary as multinationals may have more than a 100,000 suppliers. Moreover, there are a lot of additional indications on how thoroughly this due diligence should be conducted. It depends, for example, on the sector, size, region and the severity of the adverse impacts. Doing business in Congo in general requires more due diligence than doing business in Sweden. Mining for gold in conflict zones takes another form of due diligence than selling ice cream. In case the due diligence identifies the risk of an adverse impact, disengagement from supply chains should be a last-

11. See para. 43 of the Commentary to the Human Rights Chapter. resort option. The first course of action is to try and improve the situation. ${ }^{12}$

This general supply chain provision is consistent with the supply chain provisions of the UN Guiding Principles, although the OECD Guidelines now apply them to a much broader set of issues, including environmental, labour and corruption issues. ${ }^{13}$

c. Procedural Guidance

The third major achievement was the reinforcement of implementation procedures through stronger, clearer and more predictable rules for the handling of complaints by the NCPs and a stronger emphasis on problem solving through mediation. Together with a new focus on helping enterprises and other stakeholders cope with difficult situations or circumstances, this constitutes a major shift from merely expressing adhering governments' expectations to actively contributing to the prevention and resolution of conflicts arising out of MNE operations.

The procedural aspects of the NCPs have been substantially improved. One of the conceptual improvements is that NCPs now have to act in a manner that is impartial, predictable and equitable (the criteria stipulated by Ruggie for grievance mechanisms).

There are also practical improvements, such as the additional guidance for the NCP complaints procedure regarding issuing statements on cases when they are closed or dealing with parallel proceedings. Other practical improvements are for example the indicative timeframes, a binding commitment of ministers to ensure the availability of adequate human and financial resources and the possibility to start anonymous specific instances. There are also improvements aimed at better cooperation and coordination such as strengthening of the role of peer learning and the supporting role of the OECD secretariat. Finally, a new 'good faith paragraph' has been adopted, which states that parties should be genuinely engaging in the process of finding a solution. This provision does not only focus on non-cooperative behaviour of companies but is also a way to avoid unmeritorious claims or frivolous campaigns.

The focus on problem solving in the 2011 negotiations has paid off already. More and more good mediated outcomes by NCPs are reported, varying from solving environmental issues in the fisheries sector (Cermaq case; NCP Norway ${ }^{14}$ ) and contributing to eradicating child labour (Uzbekistan Cotton case; multiple $\mathrm{NCPs}^{15}$ ).

12. See para. 11 of the Commentary on the General Policies.

13. See para. 12 of the General Policies.

14. See <www.regjeringen.no/upload/UD/Vedlegg/ncp/final_statement. $\mathrm{pdf}>$.

15. See <www.gov.uk/government/uploads/system/uploads/attachment data/file/31748/11-1075-final-statement-ncp-ecchr-cargill-cotton. $p d f>$. 


\subsection{Other Substantive Revisions}

One of the innovations of the revised Guidelines is the so-called Pro Active Agenda aimed at the prevention of problems. It envisages multi-stakeholder programs or projects that deal with emerging issues, and is inspired by the work, which the OECD has conducted on minerals from conflict-affected areas. Besides the work on conflict minerals, the Pro Active Agenda has been 'filled' with projects on stakeholder engagement in the extractive industries, responsible business conduct in the financial sector and responsible sourcing in the agricultural supply chains.

Other important improvements include expanded provisions on securing morkers' rights and ensuring coherence with the ILO acquis. One of the highlights of the labour chapter revision was the inclusion of a new provision on 'living wages': 'Enterprises should “[...] in developing countries, where comparable employers may not exist, provide the best possible wages, and benefits and conditions of work [...]".'16 This provision will definitely be tested in specific instance procedures.

Another interesting new provision relates to problems that often occur in the extractive industries: Enterprises should " $[. .$.$] engage with relevant stakeholders in order to$ provide meaningful opportunities for their views to be taken into account [...]." 17 This provision is specifically targeted at planning and decision-making of important projects and focuses on local communities. Already a Pro Active Agenda project is ongoing under championship of Canada and Norway to provide further guidance on this provision.

Other new provisions adopted in the update address the topics bribe solicitation and extortion, climate-related issues, sustainable consumption, tax governance, and tax compliance.

As stated by the OECD Secretary-General Angel Gurría, the updated OECD Guidelines "will help the private sector grow their businesses responsibly by promoting human rights and boosting social development around the world". The update achieved its objective of redefining the 'gold standard' for responsible business conduct in a global context. It is considered to be a high benchmark. However, the business community also considers it to be a protection against unreasonable expectations.

\subsection{Process}

The negotiations to revise the OECD Guidelines mere very inclusive. In contrast to many international negotiations, civil society was heavily involved through stakeholder consultations. In addition, the so-called Advisory Group to the Chair also played a key role. A number of interested governments were member of this group, as well as key representatives of business (BIAC, the Business Advisory Committee to the OECD), trade unions (TUAC, the Trade Union Advisory Committee to the

16. OECD Guidelines Chapter V. Employment and Industrial Relations, para. 4.b.

17. OECD Guidelines Chapter II, para. A14 (emphasis added).
OECD) and NGOs (OECD Watch: a coalition of important NGOs).

The role of this group was to provide a sounding board for the Chair. The group provided confidential feedback to improve negotiation texts and provided also expert advice to the Chair. Using this process intensely was a way to build trust between all important stakeholders. The inclusive way to organize the negotiations turned out to be a critical success factor. During the 'endgame', the governments were in a stalemate on the supply chain texts. The mutual trust and relationship, which was built up during the months before, enabled the Chair to broker a compromise agreement between the representatives of civil society. This compromise agreement was approved by all constituents of the trade unions, NGOs and businesses, which was in itself a huge challenge. When all three stakeholder groups approved the draft agreement, the Chair could present the governments with 'an offer they couldn't refuse'.

\section{Hard Consequences}

As described in the introduction, the OECD Guidelines may be characterized as soft law with hard consequences. Although there is no system of legal sanctions in this set of non-binding principles and standards for responsible business conduct, this does not mean there are no consequences to a critical NCP statement.

First of all, civil society can use the NCP statement to lobby the company to change its behaviour. NGOs and trade unions could also, like in the Vedanta case, ${ }^{18}$ lobby the financial sector, including institutional investors, to apply pressure on the company. Many investors, like the Norwegian Oil Fund or the US Investment Fund Calvert, use the OECD Guidelines for their investments and take NCP statements very seriously.

Another link is that since 2011 NCPs are expected to share their statements with other government agencies. If governments have broader sustainability policies such as sustainable procurement policies, the relevant agencies will take into account the NCP statements, which could lead to exclusion of government procurement. Other measures that have been taken by governments include making the right to obtain diplomatic support conditional to compliance with the OECD Guidelines. This means that enterprises that would like to go on trade missions with a minister for trade need to indicate that the company adheres to the Guidelines. If there is a critical statement of the NCP, this could lead to exclusion from trade missions. In some countries, a similar link is made to financial support for foreign trade or investments.

A similar development is occurring in the field of export credits. In the recently negotiated OECD Common Approaches for Export Credit Agencies, it is stipulated that "Members should promote awareness of the OECD Guidelines for Multinational Enterprises among appro-

18. See note 3 above 
priate parties involved in applications for officially supported export credits as a tool for responsible business conduct in a global context." 19 In the Environmental and Social Due Diligence section, the following provision is adopted: "When undertaking a review, Members should, where appropriate, consider any statements or reports made publicly available by their NCPs at the conclusion of a specific instance procedure under the OECD Guidelines for Multinational Enterprises." ${ }^{20}$ In other words, export credit agencies should take into account NCP statements. That could lead to exclusion from export credit guarantees.

A more general trend is that specific fields of CSR, regulated in the form of soft lam in the OECD Guidelines, migrate to hard lam. Examples of this development are the Dodd Frank due diligence provisions on conflict minerals in the $\mathrm{US}^{21}$ and the due diligence requirements in the Forest Law Enforcement, Governance and Trade (FLEGT) regulations on timber in the EU. ${ }^{22}$

All in all, it is to be expected that compliance with the CSR norms from an ethical point of view will be completed more and more in the future with the need to comply with reinforcing forms of hard law regulation of these CSR norms.

\section{Near Future}

While this successful update was a necessary condition for a further increase of the impact of the Guidelines, it was not yet a sufficient one (alternative wording: "further revisions will still be needed"). Exploiting the updated Guidelines' potential will require sustained efforts by all involved: Adhering countries will have to review the organization and work methods of NCPs and make available the necessary resources. The OECD will have to reconsider how best to assist NCPs in their tasks as well as how to deepen its relationships and cooperation with non-adhering countries, in particular in emerging markets, and with international partners. Recently signed working arrangements, for example, with the United Nations Global Compact, the International Organization for Standardization and the Global Reporting Initiative, are important steps towards a coherent global approach to corporate responsibility.

In terms of normative coherence from the perspective of public standards, it is imperative that the OECD Working Party on Responsible Business Conduct, the OECD NCPs and the OECD Secretariat cooperate intensely with the International Labour Organization, the Office of the High Commissioner for Human Rights and the United Nations Working Group on Human Rights and
Business because they all share the same reflection of Ruggie's global standard of expected conduct in the form of soft law. It would be very unproductive and confusing to see different interpretations arise from Geneva and Paris.

Finally, MNEs, including financial service providers, will have to refine and implement their due diligence systems seriously. The new provisions will be tested in NCP specific instance procedures, so it is better to prevent problems than to have to solve them later.

\section{Bibliography}

L.C. Backer, "Rights and Accountability in Development (Raid) v Das Air and Global Witness v Afrimex: Small Steps Toward an Autonomous Transnational Legal System for the Regulation of Multinational Corporations", 10 Melbourne Fournal of International Lam, 2009 (SSRN: SSRN-id1427883-3.PDF).

G.C. Shaffer \& M.A. Pollack, "Hard vs. Soft Law: Alternatives, Complements and Antagonists in International Governance", 93 Minnesota Lam Reviem, January 2009, available at <http:// papers.ssrn.com/sol3/papers.cfm?abstract_id $=1426123>$.
19. OECD, Recommendation of the Council on Common Approaches for Officially Supported Export Credits and Environmental and Social Due Diligence (the 'Common Approaches'), as adopted by the OECD Council on Thursday 28 June 2012.

20. OECD Common Approaches, para. 15, bullet 2 .

21. Dodd Frank Act, Section 1502

22. EU Timber Regulation. Regulation (EU) No. 995/2010. 